\title{
THE RELATION BETWEEN DIGITAL GAME ADDICTIONS OF HIGH SCHOOL STUDENTS AND THEIR LEVELS OF LONELINESS
}

\author{
Burak KAYMAK ${ }^{1}$, Gülten HERGÜNER ${ }^{2}$
}

Sakarya University of Applied Sciences, Graduate Education Institute, Department of Physical Education and Sport Teaching, Sakarya/Turkey burakkaymak5@gmail.com

Sakarya University of Applied Sciences, Faculty of Sports Sciences, Sakarya/Turkey herguner@subu.edu.tr

The aim of this study is to examine the relation between digital game addictions of high school students and their loneliness levels. The study was conducted using the relational screening model.

The population of the research consists of students in Anatolian, Vocational and Technical, Fine Arts and Sports high schools, which are located in Beykoz and Ataşehir districts of Istanbul and affiliated to the Ministry of National Education, and the sampling consists of 779 high school students selected from this population using convenience sampling method. "Digital Game Addiction Scale", "UCLA Loneliness Scale" and "Personal Information Form" were used as data collection tools in the study. Descriptive statistics, independent groups ttest, one-way variance analysis (ANOVA) and
Pearson correlation analysis were applied to the collected data.

When the research findings are examined, digital game addiction scores were found to differ significantly $(p<.05)$ according to gender and school type. The loneliness level scores in the study were found to differ significantly $(p<.05)$ according to the school type; while they do not differ significantly ( $p>.05$ ) according to gender.

Finally, it was found that there was a positive low level of significant relation between digital game addiction and loneliness levels of licensed sports players and non-sports players $(p<.05)$. It was also found that the whole sample group had a positive low level of significant relation between digital game addiction and levels of loneliness $(p<.05)$.

Key Words: Digital game addiction, loneliness, student, sports 


\section{INTRODUCTION}

With the developing technology, the spread of the internet and the shrinking of digital tools to be carried in the pocket allow people to be intertwined with technology at any time and anywhere. In addition to its positive developments such as reaching every part of the world in seconds, receiving all kinds of education and information, it is driving people to become increasingly isolated and digital life addiction. Social media platforms, which offer the opportunity to socialize in virtual environments, have become an indispensable part of life, especially the young generation. So much so that even the need for communication has begun to be met through social media. And this situation leads to the widespread use of social media sites by many people for various purposes today (Yaman and Yaman, 2014). Although a person thinks that the social media environment and this emotional state are eliminated when he feels lonely, it is inevitable that he will face the same feeling of loneliness when he leaves social media tools such as phone, computer, tablet. This can cause the feeling of loneliness to deepen even more.

In today's world, where the differences between virtual and real are decreasing day by day and daily lives are replaced by virtual lives, the games played on the street have started to give way to digital games. Technological developments, the desire to distract themselves, the narrowing of physical activity areas cause individuals to turn to digital games (Tekkurşun-Demir and Bozkurt, 2019; Namlı and Tekkurşun-Demir, 2020) and facilitate the emergence of digital game addiction over time. Addiction is when a person loses control over an object or action they use and cannot live without it. In other words, the will in use and behavior disappears and the person continues the addicted use or behavior whether he wants it or not. In addition, this use and behavior takes up a serious part of life, and the person spends all his time and physical energy on the substance or action to which he is dependent, except for the jobs and relationships that he has to do (Kodaman and Dinç, 2016).

Since a significant part of daily life is spent on the Internet (Hergüner, 2011), the problematic use of computers and the Internet is also reflected in digital games today. Especially digital games, which are handled on the axis of free time activities, have an aspect such as satisfying the pleasant emotion. In the addiction dimension, it causes physical, emotional and social problems on young people. Although it is important to know what the harm of digital game addiction is to individuals and to increase awareness about digital game addiction (Hazar and others, 2017; Tekkurşun-Demir and Cicioğlu, 2020), digital game addiction is among the most important problems frequently seen in recent years. It is known that it causes many problems such as isolation from the outside world, attention deficit, aggressive behavior, violence tendency, family communication disorder, physical ailments caused by being inactive for hours, obesity, neglecting lessons and academic failure. The American Psychiatric Association (APA) suggests that digital game addiction should be considered as a disorder as a clinical diagnosis in the 3rd research annex to DSM-5 (Hazar and Hazar, 2017; Yalçın- Irmak and Erdoğan, 2015). In this context, the main purpose of this research is to reveal the relationship between digital game addiction and loneliness levels of high school students. 


\section{METHOD}

\section{Research Model}

This research, which examines the relationship between high school students' digital game addiction and loneliness levels, was carried out using the "relational screening model". Relational screening model is "research models that aim to determine the existence and/or degree of change between two or more variables" (Karasar, 2018, p. 114).

\section{Population and Sample of the Research}

The population of the research is the students of Anatolian, Vocational Technical, Fine Arts and Sports high schools in Beykoz and Ataşehir districts of Istanbul province, affiliated to the Ministry of National Education, in the fall semester of 2019-2020 education, and the sample is 779 (331 doing sports +448 not doing sports) high school students selected from this population using convenience sampling method. Convenience sampling is "the shortest way to obtain data quickly and cheaply" (Karagöz, 2017, p. 66).

Table 1: Percentage and frequency distributions regarding the demographic characteristics of the students participating in the research.

\begin{tabular}{lll}
\hline \hline Gender & $\mathrm{n}$ & $\%$ \\
\hline Male & 571 & 73,3 \\
Female & 208 & 26,7 \\
\hline Grade & $\mathrm{n}$ & $\%$ \\
\hline 9. grade & 182 & 23,4 \\
10. grade & 276 & 35,4 \\
11. grade & 220 & 28,2 \\
12. grade & 101 & 13,0 \\
\hline Licensed Sports Status & $\mathrm{n}$ & $\%$ \\
\hline Doing Sports & 331 & 42,5 \\
Not Doing Sports & 448 & 57,5 \\
\hline
\end{tabular}

Table 1 shows the distribution of students' demographic characteristics. It was determined that $73 \%(n=571)$ of the students were male; $26.7 \%(n=208)$ were female, $23.4 \%(n=182)$ were 9 th grade; $35.4 \%(n=276)$ were 10 th grade; $28.2 \%(n=220)$ were 11 th grade; $13.0 \%(n=101)$ were 12 th grade students. In addition, it was determined that $42.5 \%(n=331)$ of the students were doing sports; $57.5 \%(n=448)$ consisted of students who do not do sports.

\section{Data Collection}

This research was carried out by reaching high school students who study in Anatolian, Vocational Technical, Fine Arts and Sports high schools in Beykoz and Ataşehir districts of Istanbul province and selected by convenience sampling between the dates of 23 September-12 November 2019 in the 2019-2020 academic fall semester. After obtaining official permissions for the research, the implementation phase was carried out directly by the 
researcher at the schools where the students studied. Before the data were collected, permission was obtained by informing the school administrators, the school's guidance service and the teacher in charge of the current course. Afterwards, the purpose of the research was explained to the students with written and oral instructions, and the students who participated voluntarily signed the voluntary participation form and the measurement tools were distributed. The importance of the research was mentioned to the students and they were asked to give sincere answers as informed the measurement tools will contribute to education.

\section{Data Collection Tools}

"Personal Information Form", "Digital Game Addiction Scale" and "UCLA Loneliness Scale" were used as data collection tools in the research. Information about the measurement tools is given below.

\section{Personal Information Form}

During the preparation of the personal information form used within the scope of the research, literature research was conducted and as a result of the research, it was seen that the effects of variables such as gender, class and whether or not to do sports were more. Therefore, the researcher determined the demographic variables in this direction.

\section{Digital Game Addiction Scale}

The Digital Game Addiction (DGA-7) scale was developed by Lemmens Valkenburg and Peter (2009) and adapted into Turkish by Yalçın-Irmak and Erdoğan (2015). It is the 7-item short form of the DGA-21 scale, which consists of a total of 21 items and 7 sub-dimensions. The scale has a 5-point Likert-type, single-factor structure and scores 1-5 (1=never 5=always) points ( $\min : 7 ; \max : 35)$. As a result of the adaptation study, the Cronbach Alpha coefficient of the measurement tool was found to be .72 . As a result of the current research of the measurement tool, the Cronbach Alpha coefficient was determined as .85 .

\section{UCLA Loneliness Scale}

The UCLA loneliness scale, created by Russell, Peplau, and Ferguson (1980), is a Likert-type self-evaluation inventory used to determine the general loneliness status of the individual. The revised form of the scale has a gradation between "Totally Agree" (1) and "Totally Disagree" (4) with 20 items in total, 10 of which are positive, meaning that they do not contain semantically loneliness, and the other 10 items are negative, meaning to identify individuals who are semantically lonely. The validity and reliability studies of the scale in our country were carried out by Demir (1989). In the study of Demir (1989), the internal consistency Cronbach Alpha internal consistency coefficient of the scale was calculated as .96. As a result of the current research of the measurement tool, the Cronbach Alpha coefficient was determined as .86. 


\section{Data Analysis}

The data collected from the students were transferred to the SPSS package program by making numerical coding. First of all, the normality test for the measurement tools was performed. In the normality test, the skewness and kurtosis values of the data were examined. After the statistical process, it was determined that the data were in the range of $-2 \ldots+2$. Evidence can be given for the conformity of these values to normal distribution (George and Mallery, 2001, pp. 86-87). Since the data showed normal distribution, they were analyzed using parametric tests. In the general evaluation of the data, descriptive statistics, independent groups t-test, one-way analysis of variance (ANOVA) and Pearson correlation analyzes were used.

\section{FINDINGS}

Table 2. T-test comparison results of students' digital game addiction scores by gender.

\begin{tabular}{|c|c|c|c|c|c|c|}
\hline & Gender & $n$ & $\bar{X}$ & SS & $\mathrm{t}$ & $p$ \\
\hline Digital Game & Male & 571 & 15,85 & 6,19 & \multirow{2}{*}{9,44} & \multirow{2}{*}{01} \\
\hline Addiction & Female & 208 & 11,67 & 5,17 & & \\
\hline
\end{tabular}

Independent groups t-test results in Table 2 show that digital game addiction scores differ according to gender $\left(t_{(777)}=9.44 ; p<.05\right)$.

Table 3. One-way analysis of variance comparison results of students' digital game addiction scores according to school type.

\begin{tabular}{|c|c|c|c|c|c|c|c|}
\hline & High School Types & $\mathrm{n}$ & $\bar{X}$ & ss & $\mathrm{F}$ & $\mathrm{p}$ & Difference \\
\hline \multirow{4}{*}{$\begin{array}{l}\text { Digital } \\
\text { Game } \\
\text { Addiction }\end{array}$} & 1) Fine Arts High School & 100 & 14,39 & 6,73 & \multirow{4}{*}{6,31} & \multirow{4}{*}{01} & \multirow{4}{*}{$4>2$} \\
\hline & 2) Anatolian High School & 279 & 13,60 & 5,71 & & & \\
\hline & 3) Vocational Technical High School & 145 & 15,17 & 5,74 & & & \\
\hline & 4) Sports High School & 255 & 15,85 & 6,59 & & & \\
\hline
\end{tabular}

One-way analysis of variance (ANOVA) results in Table 3 show that there is a statistically significant difference in digital game addiction scores of students according to school type $\left(F_{(778)}=6.31 ; p<.05\right)$. According to the Post Hoc (SCHEFFE) results made to determine the source of the difference, the digital game addiction scores of the sports high school students are significantly higher than the Anatolian high school students.

Table 4. T-test comparison results of students' loneliness level scores by gender.

\begin{tabular}{lllllll}
\hline \hline & Gender & $\mathrm{n}$ & $\overline{\mathrm{X}}$ & $\mathrm{ss}$ & $\mathrm{t}$ & $\mathrm{p}$ \\
\hline $\begin{array}{l}\text { Loneliness } \\
\text { level }\end{array}$ & Male & 571 & 37,35 & 10,86 & \multirow{2}{*}{$-1,51$} & \multirow{2}{*}{, 13} \\
\cline { 2 - 5 } & Female & 208 & 38,69 & 11,10 & & \\
\hline
\end{tabular}

Independent groups t-test analysis results in Table 4 show that loneliness level scores do not differ according to gender $\left(t_{(777)}=-1.51 ; p>.05\right)$. 
Table 5. One-way analysis of variance comparison results of students' loneliness level scores according to school type.

\begin{tabular}{|c|c|c|c|c|c|c|c|}
\hline & High School Types & $\mathrm{n}$ & $\overline{\mathrm{X}}$ & SS & $\mathrm{F}$ & $\mathrm{p}$ & Difference \\
\hline \multirow{4}{*}{ Loneliness } & 1) Fine Arts High School & 100 & 40,82 & 10,88 & \multirow{4}{*}{3,19} & \multirow{4}{*}{,02 } & \multirow{4}{*}{$1>2$} \\
\hline & 2) Anatolian High School & 279 & 37,22 & 11,07 & & & \\
\hline & 3) Vocational Technical High School & 145 & 36,94 & 9,94 & & & \\
\hline & 4) Sports High School & 255 & 37,47 & 11,20 & & & \\
\hline
\end{tabular}

The one-way analysis of variance (ANOVA) results in Table 5 show that there is a statistically significant difference in the loneliness level scores of the students according to the school type $(F(778)=3.19 ; p<.05)$. According to the Post Hoc (SCHEFFE) results made to determine the source of the difference, the loneliness level scores of the fine arts high school students are significantly higher than the scores of the Anatolian high school students.

Table 6. The results of the relationship between digital game addiction and loneliness levels scores according to the status of students doing or not doing licensed sports.

\begin{tabular}{|c|c|c|c|}
\hline Licensed Sports Status & & & Loneliness \\
\hline \multirow{2}{*}{ Doing Sports } & \multirow{2}{*}{ Digital Game Addiction } & $r$ & ,286 \\
\hline & & $p$ & $001 * *$ \\
\hline \multirow{2}{*}{ Not Doing Sports } & \multirow{2}{*}{ Digital Game Addiction } & $r$ & 197 \\
\hline & & $p$ &, $001 * *$ \\
\hline
\end{tabular}

The results of the Pearson correlation analysis in Table 6 were positively low $(r=.286 ; p<.05)$ between digital game addiction and loneliness levels in licensed sports players; showed that there is a low level of positive relation between digital game addiction and loneliness levels $(r=.286 ; p<.05)$ in those who do not licensed sports.

Table 7. The results of the relationship between students' digital game addiction and loneliness levels scores.

\begin{tabular}{lll}
\hline \hline & & Loneliness \\
\hline \multirow{2}{*}{ Digital Game Addiction } & $\mathrm{r}$ &, 231 \\
\cline { 2 - 3 } & $\mathrm{p}$ &, $000^{* *}$ \\
\hline
\end{tabular}

The results of Pearson correlation analysis in Table 7 showed that there was a low level of positive relation between students' digital game addiction and loneliness levels ( $r=.231 ; p<.05)$.

\section{DISCUSSION AND CONCLUSION}

It was aimed to reveal the relationship between high school students' digital game addictions and their loneliness levels in this research.

When the findings regarding the digital game addiction of the students participating in the research were evaluated according to the gender variable, it was determined that the digital game addiction was significantly higher in male students than in female students. It is seen that these findings obtained according to the gender 
variable show parallelism with the literature. As a matter of fact, in the studies conducted in this field in the literature, it has been found that students' digital game addictions or internet addictions differ significantly (Vaizoglu and others, 2004; Ekinci and others, 2016; Bonanno and Kommers, 2005) and addiction level is high in favor of male students (Bayram and Gündoğmuş, 2016; Chou and Hsiao, 2000; Çakır-Balta and Horzum, 2008). When the results obtained in the research and the results of previous studies in this field in the literature are evaluated, it can be said that among high school students, digital game addiction is higher in male students than in female students (Göldağ, 2018; Horzum, 2011; Köseliören, 2017; Solak, 2012).

When it is considered according to the variable of high school type of education, it was determined that the digital game addictions of the students participating in the research differed significantly, and according to the findings, it was found that the digital game addiction was higher in Sports High School students when compared to the Anatolian High School students. It can be thought that the reason for the difference in digital game addictions of students according to the type of high school education is that the course load and free time of the students differ according to the type of high school they study, and the time period they allocate to digital games varies in parallel. In the literature, the results of the research show that digital game addiction differs according to the type of high school studied (Solak, 2012). In addition, it was found that the level of students' preference for digital games over other activities differed significantly according to the type of high school they study (Köseliören, 2017).

It was found that the loneliness levels of the high school students participating in the study did not differ significantly according to the gender variable. In studies dealing with the loneliness levels of high school students, it can be thought that the reason for the differences according to the gender variable is the fact that the students live in different socio-cultural environments and that their friendships are different from each other. In the literature, it has been reported that in some studies conducted on students studying at different education levels, the loneliness levels of students do not differ significantly according to the gender variable (Ekinci and others, 2016; Erözkan, 2009), while in some studies, the loneliness levels of students differ according to gender (Karakoç and Taydaş, 2013; Solak, 2012).

It was determined that the loneliness levels of the students participating in the study differed significantly when the school type was studied according to the variable, and according to the findings, it was found that the loneliness levels of the Fine Arts High School students were higher when compared to the Anatolian High School students. In similar studies in the literature, it has been reported that students' loneliness levels show some differences according to school or department type (Buluş, 1997). In this context, it can be said that the findings obtained according to the school type variable show parallelism with the literature. On the other hand, in some studies in the literature, there are also study results revealing that the loneliness levels of high school students do not differ significantly according to the variable of high school type (Solak, 2012; Döner, 2018; Erözkan, 2009). 
In the study, it was determined that there is a positive and significant relationship between digital game addiction and loneliness level in high school students who do or do not do sports under license. It is known that addiction to digital technologies increases the level of loneliness in people, and research findings in the literature support this view (Aktaş and Yılmaz, 2017; Bian and Leung, 2014; Morahan-Martin and Schumacher, 2000; Döner, 2018; Mert and Özdemir, 2018; Oktan, 2015). In this context, it can be said that the findings obtained in this study are compatible with the literature. In similar studies conducted on students studying at different education levels in the literature, it has been reported that as the level of digital game addiction increases, the level of loneliness also increases (Balcı, 2018; Çakır and Çetinkaya, 2019; Torun and others, 2015; Ekinci and others, 2019; Koyuncu and others, 2014).

It can be thought that the reason for the positive and significant relationship between digital game addiction and loneliness lies in the fact that students addicted to digital games become anti-social individuals over time and make the virtual environment their basic living space by isolating themselves from society. In the studies in the literature, digital game addiction paves the way for anti-social personality over time (Budak, 2017, p; Kowert and Oldmeadow, 2013; Çuhadar, 2012; Kim and others, 2008) has been reported to isolate people accordingly. In a study conducted on secondary school students on this subject, it was determined that as the digital game addiction of the students increased, their relations with their friends deteriorated, and the students found spending time in the virtual environment more enjoyable than spending time with their friends. In the same study, it was concluded that $15.2 \%$ of the students sometimes felt lonely and $7.5 \%$ of them often felt lonely (Çelik and Ulusoy, 2019).

Although it is seen that digital game addiction predicts the level of loneliness in the studies on students in the literature, the research findings conducted on the students' parents also support the view that there is a significant relationship between digital game addiction and the level of loneliness. In a study conducted by Çelik and Ulusoy (2019) on the parents of students on this subject, it was reported that as the level of addiction of their children to computer games increases, the level of loneliness also increases, according to the opinions of the parents. In the compilation study conducted by Jeong and others (2016), the effects of digital game addiction on the relationship between aggression, depression and loneliness were discussed in the light of different research findings. According to the findings of the study, it has been reported that digital game addiction increases the tendency to aggression and depression, and in parallel, the loneliness levels of individuals with digital game addiction increase.

As can be seen, digital game addiction in high school students and the time spent at the beginning of electronic technologies negatively affect their psycho-social structures (Vaizoğlu and others, 2004). In a limited number of studies in the literature, it has been reported that there is no significant relationship between digital game addiction and students' loneliness levels (Solak, 2012). 
As a result; It has been seen that digital game addiction of high school students is an element that increases the level of loneliness. At this point, awareness raising activities can be carried out to prevent digital game addiction in order to minimize the loneliness levels of students. In addition, by being directed to various arts and sports activities, it can be ensured that they have a social environment and reduce their loneliness level. The research is limited to high school students in Beykoz and Ataşehir districts of Istanbul and selected for the research. Studies can be conducted in which a larger sample group will be selected. In addition, the research was conducted at the high school level. Similar studies can be planned at different levels of education (primary school, secondary school and university). In order to investigate the effects of digital gaming and loneliness on young people, studies can be conducted in Turkey and regionally. Finally, performance can be performed on athletes and according to branches.

\section{REFERENCES}

Aktaş, H., \& Yılmaz, N. (2017). Üniversite gençlerinin yalnızlık ve utangaçlık unsurları açısından akıllı telefon bağımlılı̆ı. International Journal of Social Sciences and Education Research, 3(1), 85-100.

Balcı, N. (2018). Lise öğrencilerinde çocukluk çağı travmaları ve yalnızlık düzeyi ile internet bağımlılı̆ı arasındaki ilişkinin incelenmesi (Yüksek Lisans Tezi). Beykent Üniversitesi, Sosyal Bilimler Enstitüsü, Ankara.

Bayram, S. B., \& Gündoğmuş, G. (2016). İlköğretim öğrencilerinin internet bağımlılığı eğilimlerinin ve yalnızlık düzeylerinin çeşitli değişkenlere göre incelenmesi. Akademik Bakış Uluslararası Hakemli Sosyal Bilimler Dergisi, 54, 307-318.

Bian, M., \& Leung, L. (2014). Smartphone addiction: Linking loneliness, shyness, symptoms and patterns of use to social capital. Media Asia, 41(2), 159-176.

Bonanno, P., \& Kommers, P. A. (2005). Gender differences and styles in the use of digital games. Educational Psychology, 25(1), 13-41.

Budak, O. (2017). Dijital çocuk oyunlarına çocuk gelişimi ve okul öncesi öğretmenlerinin ve annelerin bakış açısı. Uluslararası Eğitim Bilimleri Dergisi, (13), 158-172.

Buluş, M. (1997). Üniversite öğrencilerinde yalnızlık. Pamukkale Üniversitesi Eğitim Fakültesi Dergisi, 3(3), 82-90.

Çakır, O., \& Çetinkaya, A. (2019). Time spent on the internet, blood pressure and loneliness in adolescents: a cross-sectional study. Erciyes Medical Journal, 41(4), 1-7.

Çakır-Balta, Ö., \& Horzum, M. B. (2008). The factors that affect internet addiction of students in a web based learning environment. Ankara University Journal of Faculty of Educational Sciences, 41(1), 187-205.

Çelik, S., \& Ulusoy, B. (2019). Bilgisayar oyunlarının ortaokul öğrencilerinin sosyal yaşamına etkisi. The Journal Of Social Science, 3(5), 46-60.

Chou, C., \& Hsiao, M. C. (2000). Internet addiction, usage, gratification, and pleasure experience: the Taiwan college students' case. Computers \& Education, 35(1), 65-80.

Çuhadar, C. (2012). Exploration of problematic Internet use and social interaction anxiety among Turkish preservice teachers. Computers \& Education, 59(2), 173-181.

Demir, A. (1989). UCLA yalnızlık ölçeğinin geçerlik ve güvenirliği. Psikoloji dergisi, 7(23), 14-18. 
Döner, M. (2018). Özel lise öğrencilerinin yalnizlik ve umutsuzluk düzeyleriyle internet bağimliliği düzeyleri arasindaki ilişkinin incelenmesi (Yüksek Lisans Tezi). İstanbul Gelişim Üniversitesi, Sosyal Bilimler Enstitüsü, i̇stanbul.

Ekinci, N. E., Dogan-Ustun, U., \& Ozer, O. (2016). An Investigation of the relationship between digital game addiction, gender and regular sport participation. Online Submission, 7(2), 298-303.

Ekinci, N. E., Yalcin, I., \& Ayhan, C. (2019). analysis of loneliness levels and digital game addiction of middle school students according to various variables. World Journal of Education, 9(1), 20-27.

Erözkan, A. (2009). The predictors of loneliness in adolescents. Ilkogretim Online, 8(3).

George, D., \& Mallery, P. (2001). SPSS for windows step by step: A simple guide and reference 10.0 update. (3. Baskı). Boston: Allyn and Bacon.

Göldağ, B. (2018). Lise öğrencilerinin dijital oyun bağımlılık düzeylerinin demografik özelliklerine göre incelenmesi. Yüzüncü Yıl Üniversitesi Eğitim Fakültesi Dergisi , 15 (1) , 1287-1315 .

Hazar, Z., Tekkurşun-Demir, G., Namlı, S., \& Türkeli, A. (2017). Ortaokul öğrencilerinin dijital oyun bağımlılığı ve fiziksel aktivite düzeyleri arasındaki ilişkinin incelenmesi. Beden Eğitimi ve Spor Bilimleri Dergisi, 11(3), 320-332.

Hazar, Z.,\& Hazar, M. (2017). Çocuklar için dijital oyun bağımlılığı ölçeği. Journal of Human Sciences, 14(1), 203216.

Hergüner, G. (2011). Opinions of students in physical education and sports teaching on the use of social network sites. Turkish Online Journal of Educational Technology-TOJET, 10(2), 174-183.

Horzum, M.B. (2011). İlköğretim öğrencilerinin bilgisayar oyunu bağımlılık düzeylerinin çeşitli değişkenlere göre incelenmesi. Eğitim ve Bilim, 36(159).

Jeong, E. J., Kim, D. J., Lee, D. M., \& Lee, H. R. (2016, January). A study of digital game addiction from aggression, loneliness and depression perspectives. In 2016 49Th Hawaii International Conference On System Sciences (HICSS) (pp. 3769-3780). IEEE.

Karagöz, H. (2017). SPSS ve AMOS uygulamalı nitel-nicel-karma bilimsel araştırma yöntemleri ve yayın etiği (1. Baskı). İstanbul: Nobel Kitabevi.

Karakoç, E., \& Taydaş, O. (2013). Bir serbest zaman etkinliği olarak üniversite öğrencilerinin internet kullanimi ile yalnizlik arasindaki. Selçuk Üniversitesi Iletişim Fakültesi Akademik Dergisi, 7(4), 33-45.

Karasar, N. (2018). Bilimsel araştırma yöntemleri: Kavramlar, ilkeler ve teknikler. (32.Baskı). Ankara: Nobel Yayın Dağıtım.

Kim, E. J., Namkoong, K., Ku, T., \& Kim, S. J. (2008). The relationship between online game addiction and aggression, self-control and narcissistic personality traits. European Psychiatry, 23(3), 212-218.

Kodaman, U., \& Dinç, M. (2016). Teknolojiye bağımlı yaşama. İstanbul: Kültür Sanat Basımevi.

Köseliören, M. (2017). Internet, online oyun ve bağımlılık (Yüksek Lisans Tezi). Selçuk Üniversitesi, Sosyal Bilimler Enstitüsü, Konya.

Kowert, R., \& Oldmeadow, J. A. (2013). (A) Social reputation: Exploring the relationship between online video game involvement and social competence. Computers in Human Behavior, 29(4), 1872-1878.

Koyuncu, T., Unsal, A., \& Arslantas, D. (2014). Assessment of internet addiction and loneliness in secondary and high school students. J Pak Med Assoc, 64(9), 998-1002. 
Lemmens, J.S., Valkenburg, P.M., \& Peter, J. (2009). Development and validation of a game addiction scale for adolescents. Media Psychology 12(Suppl.1):77-95.

Mert, A., \& Özdemir, G. (2018). Yalnızlık duygusunun akılı telefon bağımlılığına etkisi. OPUS Uluslararası Toplum Araştırmaları Dergisi, 8(1), 88-107.

Morahan-Martin, J., \& Schumacher, P. (2000). Incidence and correlates of pathological Internet use among college students. Computers in Human Behavior, 16(1), 13-29.

Namlı, S., \& Tekkurşun-Demir, G. (2020). The relationship between attitudes towards digital gaming and sports. Turkish Online Journal of Educational Technology-TOJET, 19(1), 40-52.

Oktan, V. (2015). Üniversite öğrencilerinde problemli internet kullanımı, yalnızlık ve algılanan sosyal destek. Kastamonu Eğitim Dergisi, 23(1), 281-292.

Russell, D., Peplau, L. A., \& Cutrona, C. E. (1980). The revised UCLA Loneliness Scale: concurrent and discriminant validity evidence. Journal of Personality and Social Psychology, 39(3), 472.

Solak, M.Ş. (2012). Ortaöğretim öğrencilerinin bilgisayar oyunu tutumları ile saldırganlık ve yalnızlık eğilimleri arasındaki ilişkilerin incelenmesi (Yüksek Lisans Tezi). Marmara Üniversitesi Eğitim Bilimleri Enstitüsü, İstanbul.

Tekkurşun-Demir, G., \& Bozkurt, T. M. (2019). Dijital oyun oynama tutumu ölçeği (DOOTÖ): Geçerlik ve güvenirlik çalışması. Sportif Bakış: Spor ve Eğitim Bilimleri Dergisi, 6(1), 1-18.

Tekkurşun-Demir, G., \& Cicioğlu, H. i. (2020). Dijital oyun bağımlılığına ilişkin farkındalık ölçeği (DOBiFÖ): geçerlik ve güvenirlik çalışması. Avrasya Spor Bilimleri Ve Eğitim Dergisi, 2(1), 1-17.

Torun, F., Akcay, A., \& Coklar, A. N. (2015). Analyzing of computer games effects on social life and academic behavior of the secondary school students. Karaelmas Journal of Educational Sciences, 3, 25-35.

Vaizoglu, S. A., Aslan, D., Gormus, U., Unluguzel, G., Ozemri, S., Akkus, A., \& Guler, C. (2004). Internet use among high school students in Ankara, Turkey. Saudi Medical Journal, 25(6), 737-740.

Yalçın Irmak, A., \& Erdoğan, S. (2015). Ergen ve genç erişkinlerde dijital oyun bağımlılığı: Güncel bir bakış. Anadolu Psikiyatri Dergisi. 27.2, 10-18.

Yalçın-Irmak, A., \& Erdoğan, S. (2015). Dijital oyun bağımlılığı ölçeği Türkçe formunun geçerliliği ve güvenilirliği. Anatolian Journal of Psychiatry/Anadolu Psikiyatri Dergisi, 16.

Yaman, M., \& Yaman, Ç. (2014). The use of social network sites by prospective physical education and sports teachers (Gazi University Sample). Turkish Online Journal of Educational Technology-TOJET, 13(1), 223231. 